\title{
HEAT RECOVERY OF COMPOST REACTORS: FIELD STUDY OF OPERATIONAL BEHAVIOUR, HEATING POWER AND INFLUENCE FACTORS
}

\begin{abstract}
This study evaluates the common process and set-up design of a static compost bioreactor for heat recovery. A technology, which fits the goal of a sustainable, growing bioeconomy which combines the utilization of compost heat and compost material. Interest on this technology has been growing the last years but precise data of pilot scale reactors is rare. Data is required to adjust the process for custom needs and further technical development. Therefore, lignin-cellulose based biomass was composted in unaerated cylindrical compost reactors size 20 to $70 \mathrm{~m}^{3}$ for 140 days. The biomass comes with C:N ratio of about 25:1, water content of 43-48\%, organic matter content of $40.6 \%$ d.m. and calorific value of $8.3 \mathrm{MJ} / \mathrm{kg} \mathrm{d}$.m. Spatial distribution of temperature and gas concentration (oxygen, carbon dioxide, methane) within the reactor shows methane production of the anaerobic core area. Maximum thermal power of $5.2 \mathrm{~kW}$ from a $63 \mathrm{~m}^{3}$ reactor with average temperature of heating flow about $40{ }^{\circ} \mathrm{C}$ was reached. Maximum recovered heating power of $4.8 \mathrm{MJ} / \mathrm{kg} \mathrm{d}$.m. was calculated for an operation of 6 month. This corresponds to $50 \%$ of the measured calorific value. Biggest influence factors detected on the recovered heating power of the pilot scale reactor has been the size of reactor, the set up quality and the control of heat exchanger. The spatial correlation between heat production and aerobic digestion suggests a technical development in terms of aeration.
\end{abstract}

Keywords: biomass energy, composting, passive aeration, heat exchanger, gas concentration

\section{Introduction}

The EU's Strategy on Heating \& Cooling [1] focus the political action on these sectors. They account for around $50 \%$ of final energy consumption in the EU and Germany. The strategy demands further efforts to expand renewable energies to meet the EU's $\mathrm{CO}_{2}$-Reduction-Targets. In Germany, the amount of renewable energies in consumer energy supply for heating and cooling is $13.9 \%$ in 2018 . With $84 \%$, the bioenergy sector (without landfill, sewage gas) contributes by far the most to these renewable energy sources [2].

Sustainability criteria in renewable energy regulations were established for the Member States to ensure the sustainable use of biomass sources and to avoid further indirect land use changes through the cultivation of energy crops [3]. Therefore residuals are to be acquire for energetic use to avoid (land-) use competitions with food and feed production. A growing bio-based economy (Bioeconomy), which aims for resource-conserving, cycle-oriented management systems and thus also the inclusion of the

\footnotetext{
${ }^{1}$ Deutsches Biomasseforschungszentrum, Bioenergy Systems Department, Working Group Biomass in the Energy System, Torgauer Straße 116, 04347 Leipzig, Germany, phone +49 (0)341 2434-112, email: info@dbfz.de

*Corresponding author: nele.jaschke@posteo.de
} 
waste, searches for suitable synergy potentials through the use of cascades and value chains [4].

Residue monitoring in Germany [5] revealed that f.e. green cuts have still an available potential. Greencuts include grass cuttings from grassland, woody cuttings from home gardens, parks, cemeteries as well as landscape and roadside green care. The theoretical amount is about 7,808,000 $\mathrm{t}$ (tonne $=10^{6} \mathrm{Mg}$ ) of dry matter (d.m.). According to the analysis about 2,319,000 t d.m. can be acquired and about 3,639,000 t d.m. have been used only materially for composting without previous energetic use.

The majority of the greencuts are disposed in composting sites, where it is converted to compost in the shortest possible time due to the costs of space capacity. So far, agricultural holdings are using around $90 \%$ of the compost [6]. The national implementation of the EC Nitrates Directive (91/676/EEC) [7] by the Fertilizers Act and Regulations make the use of compost in the agricultural sector much more difficult and reduces the application (annual limits for nitrogen and application timeframes). This leads to additional environmental regulations for storage and a significant increase in composting costs in the past few years. With a higher-value utilization of the greencuts, this development could be slowed down.

An energetic utilization of the inhomogeneous greencuts is challenging. Due to the lignin content of the woody compartments, fermentation in biogas plants is difficult. The small diameter of shrub and branch material, the high proportion of bark, and the high water content make it unattractive to use in large combined thermochemical heat and power plants. Further, both, the biogas technology and the combined thermochemical heat and power plants have bigger economies of scale than adequate to the strongly decentralised distribution of the green cut mass flows. So far, there is no optimal utilization of this biomass in the material and energetic cycles [8, 9]. In addition, in case of burning, the material is not available for humus reproduction any more.

With compost reactors with integrated heat recovery technologies, the green wastes can be used energetically and materially. This reactors use the heat released during composting process for heating purposes to replace fossil fuels and to gain associated GHG savings. With this, aforementioned gap could be closed in the future.

There are several ways to extract heat from the composting process (Table 1). The two most common variants are no. 2 and 4. So far, there are hardly any scientifically documented, systematic examinations of these systems on a pilot scale, which foreclose an evaluation of the operating mode and economic aspects [10-12]. Model calculations of preliminary studies have shown that the pilot variants performance differ by a factor of 10 and the investments by a factor of 100 comparing low tech and high tech variants [11].

Additional, data from lab scale experiments are not transferable on pilot scale due to the surface-to-volume ratio ( $A: V$ ratio), which influence physical parameters (density, aeration flow distribution, water balance) and microbial heat production (minimum reactor volume, heat loss, multiple trials) [13-15]. Despite the apparent drawbacks of internal heat exchanging systems [10], the publication of concrete operating data is therefore desirable.

In this study, selected operational data of eleven compost reactors with internal heat exchangers were analysed with regard to substrate properties, substrate degradation as well as temperature and gas concentration profiles. The recovered heating power and heat efficiency was calculated to evaluate influence factors on maximum heating power. 
Types of heat extraction from the composting process and selection of corresponding authors and publications

\begin{tabular}{|c|c|c|c|c|}
\hline \multicolumn{4}{|c|}{ Type of heat extraction } & Author \\
\hline \multicolumn{2}{|c|}{ No heat exchanger technology } & Direct use & 1 & {$[16,17]$} \\
\hline \multirow{5}{*}{ Heat exchanger } & \multirow{2}{*}{ internal } & within biomass & $2^{*}$ & {$[18,19]$} \\
\hline & & within reactor borders & 3 & [19-21] \\
\hline & \multirow{3}{*}{ external } & exhaust air & $4^{*}$ & [21-29] \\
\hline & & leachate & 5 & [19] \\
\hline & & radiant heat & 6 & [25] \\
\hline
\end{tabular}

* most common variants

\section{Material and methods}

\section{Substrate properties}

The substrate consists mainly of greencuts and shrubbery as well as grass, straw, garden waste and soil residues. The biomass was collected over a period of two months (March-April) from small suppliers and is already in the decomposition process at the time of reactor set-up. The biomass for $720 \mathrm{~m}^{3}$ substrate was shredded with a Doppstadt shredder, basket width $0.18 \mathrm{~m}$, simultaneously to construction process. Due to various types of biomass material and the steps of shredding, loading, unloading and pushing over with the wheel loader, the substrate was considered as homogeneously mixed for the experiment.

The substrate sampling was carried out as a mixed sample on two days from the substrate depot during set up of the reactors. Sampling of the produced compost was done from reactor 4A and 4B. The degradation degree $\eta$ was calculated with equation [30]:

$$
\eta=1-\frac{O D M_{\text {output }} \cdot\left(1-O D M_{\text {Input }}\right)}{O D M_{\text {Input }} \cdot\left(1-O D M_{\text {Output }}\right)}
$$

\section{Experimental plant and reactor set-up}

From $6^{\text {th }}$ May to $15^{\text {th }}$ September 2017 eleven compost reactors of $21-70 \mathrm{~m}^{3}$ for nightly heating of tropical plants were operated in Lutherstadt Wittenberg, Germany (Fig. 1b).

a)

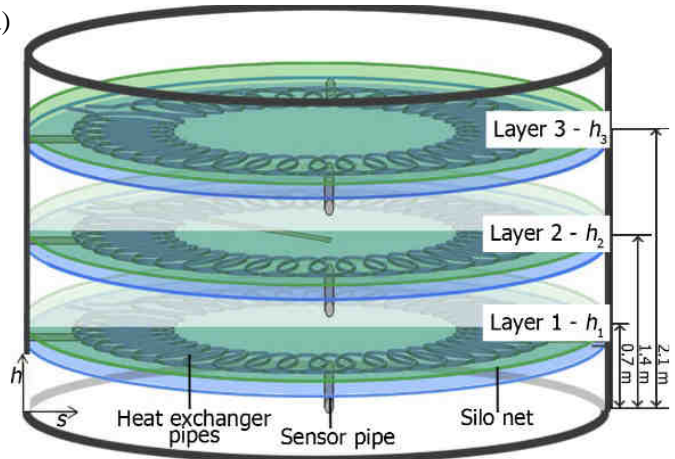

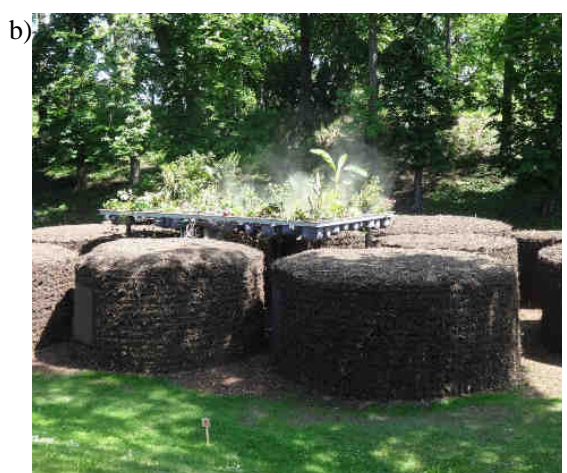

Fig. 1. a) Standard experimental set-up of reactors, b) photo of experimental plant with compost reactors

The experimental plant was located in a landscape sink protected from weather influence. The reactors were disposed only to the sun and mild winds from South-West. 
The ambient temperature in trial period was mostly $>15^{\circ} \mathrm{C}$, except at some nights and during first 15 days of trial (Fig. A.1) ${ }^{2}$. Due to few rain events, weather was considered homogeneous.

The basic reactor set-up corresponds to the empirical experience of the builder "Native Power e.V." and complied with the current state of technology: Comprising an unaerated static pile with cylindrical shape and inserted, water filled pipe-loop heat exchangers. The three heat exchangers with $100 \mathrm{~m}$ length each are placed in pipe loops on three layers (blue, Fig. 1a). For an easier deconstruction, the builder integrated a silo mesh above each heat exchanger layer that can be drawn back by a wheel loader (green, Fig. 1a). No aeration applications are added, so the system is aerated solely passively. All used components and devices are listed in Table A.1.

A size category for analyses was chosen because heat development depends on oxygen supply and in passively aerated reactors, oxygen supply depends on $A: V$ ratio. The nomenclature of the compost reactors include the radius-dependent size category ( 1 to 4) and the location on the experimental plant (A to D) (Fig. 2 and Table A.2).

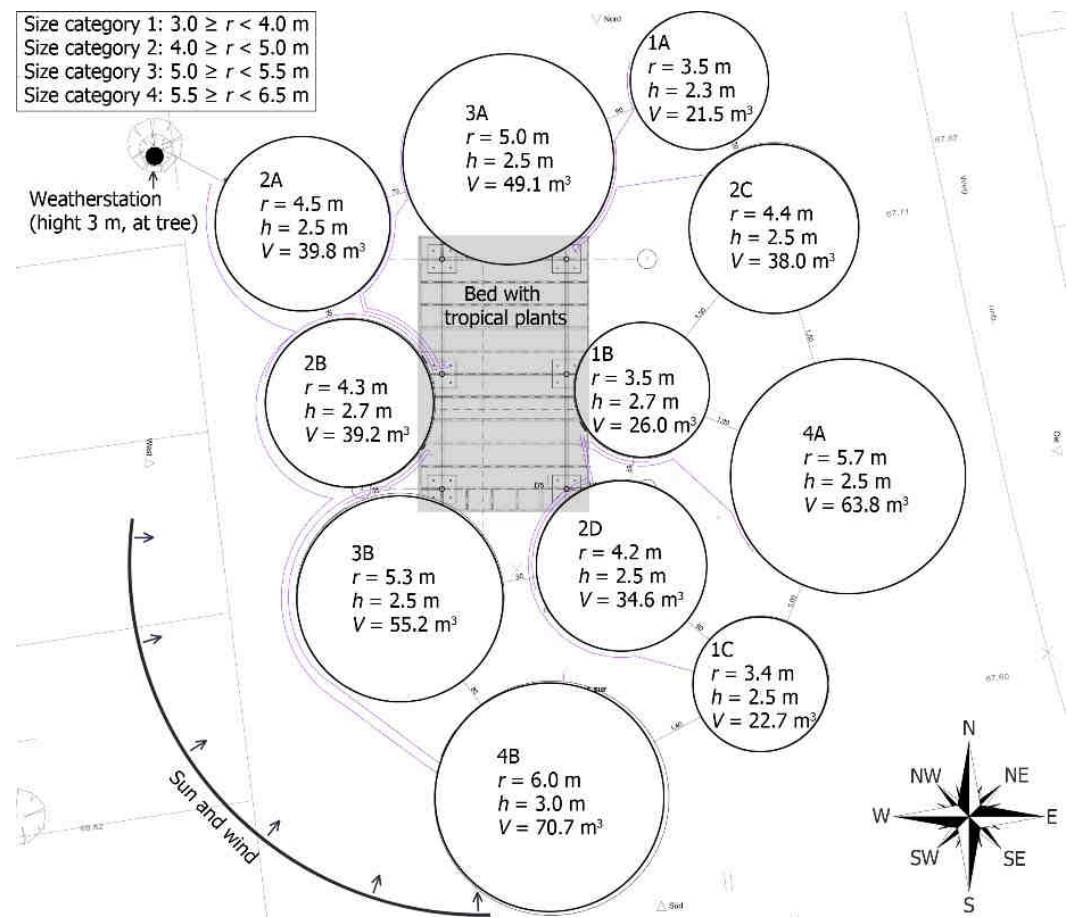

Fig. 2. Experimental plant and reactor specifications

It is assumed that differences in substrate properties as well as the vertical temperature and gas concentration profile of the reactor are formed solely by the set up and operating mode. Furthermore, a rotationally symmetric distribution of the measured values in the cylindrical reactor space can be assumed as shown in [11]. Therefore the reactor is divided

\footnotetext{
${ }^{2}$ Fig. A.1 and Tables A.1-A.4 are available in Supplementary materials
} 
into the reactor border and three areas (Fig. 3a): I. Border area $(s \leq 0.5 \mathrm{~m})$, II. Transmission area $(0.5 \mathrm{~m}<s \leq 1.5 \mathrm{~m})$, III. Core area $(s>1.5 \mathrm{~m})$.

a)

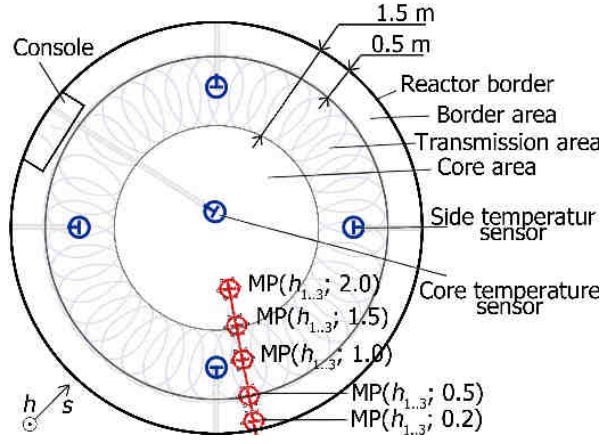

b)

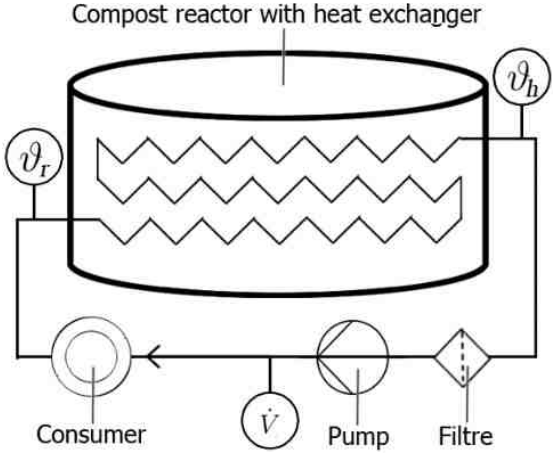

Fig. 3. a) Automated (blue) and manual (red) measure points (MP) for temperature and gas concentration, b) scheme of heating circuit for each reactor set-up

\section{Heat exchanger control and trial time}

Each reactor has its own heating circuit with its own pump, filter and heat consumer, which leads to different flow rates and return flow temperatures (Fig. 3b). The power supply of the heat circuit pumps were coupled and controlled centrally by simply switching on and off. The consumers needed heat only during nighttime. That's why for operational behaviour an interval switching of 12 hours was chosen: Heat extraction runs from every 9 o'clock p.m. to 9 o'clock a.m., gives recovery time for the rest of the daytime.

The set up of all compost reactors took seven days. On day ten $\left(6^{\text {th }}\right.$ May 2017 , three days after setting up the last reactors 4A, 4B and 1C) heat exchanger operation was started. At this time the thermophilic phase of these three reactors was yet not reached, causing a delay of compost process of these reactors till pump operation pause after day 62 (Fig. 6). During the first day of operation, the pipe loop heat exchangers were rinsed with water solely to remove air from the pipes. From day eleven on, the heat exchanger was operated continuously. After 40 days the 12-hour-interval switching started.

\section{Sensors and reactor measurements}

The temperature in the compost reactor was automatically measured by 13 sensors (blue, Fig. 3a). Positions of the sensors were: 4 sensors on each layer $\left(h_{1 . .3}\right)$ in $1 \mathrm{~m}$ depth and $0.05 \mathrm{~m}$ below the heat exchangers and additional one sensor in the centre on Layer 2 $\left(h_{2}\right)$. Figure $3 \mathrm{~b}$ shows two automated temperature measurements in the heating and return flow of heating circuit. The temperature sensors in the biomass had a measurement accuracy of $\pm 0.5 \mathrm{~K}$ and the sensors in the heating circuit were calibrated to $\pm 0.1 \mathrm{~K}$. The system used a Raspberry Pi and an online database for data backup. The interrogator rhythm was $120 \mathrm{~s}$. As shown in Figure $3 \mathrm{~b}$ the volume flow was measured with a flow meter (53 pulses are $1 \mathrm{~L}$ ). The absolute error results from the pulses to $0.02 \mathrm{~L} /$ pulse.

Furthermore, manual measurements points $\operatorname{MP}(h ; s)$ were defined to measure the vertical temperature and gas concentration profile (red, Fig. 3a). Therefore, temperature was measured with a temperature lance with accuracy $\pm 1 \mathrm{~K}$. The gas samples were taken 
with a substrate lance and analysed with a biogas monitor. Biogas monitor accuracy is shown in Table A.3. All used devices are listed in Table A.1.

\section{Choice of reactors for analysis}

All reactors were compared regarding temperature range level, heat production and influence factors. As there was only one size category with four reactors (category 2), these were evaluated with regard to their operating behaviour because of trial size. This included the operation of a reference reactor (2C) and a heat exchanger stop after 56 days (2D). Reactors size category 4 had the highest temporary recovered heating power and therefore compost material samples were taken from them. All reactors and specifications are listed in Table A.2. Recovered heating power was calculated with:

$$
\dot{Q}=\dot{V} \cdot \rho_{W} \cdot c_{W} \cdot\left(\vartheta_{h}-\vartheta_{r}\right)
$$

\section{Statistical analyses}

The figure generation of the vertical profile of temperature and gas concentrations are carried out with the statistic program $\mathrm{R}$. R uses matrices as a representation basis and interpolates linearly between the measuring points. For this purpose, the data from 15 to 22 MP were initially subjected to a plausibility check and existing data gaps were linearly interpolated. Representative 3 measurements are shown for a concise presentation (Figs. 8 and 9).

\section{Results}

\section{Substrate degradation}

The substrate properties are shown in Table 2. The substrate has optimal moisture $(W)$ and $\mathrm{C}: \mathrm{N}$ ratio for composting process [31]. The substrate was already in the decomposition process at the time of set-up because of the collection period of 2 month. That's shown by the relatively low organic matter content $(O D M)$, calorific value $\left(c_{m}\right)$ and especially by the particle size distribution (Fig. 4). With fresh material and low mineral content a $O D M$ $>60 \%, c_{m}>10 \mathrm{MJ} / \mathrm{kg} \mathrm{d}$.m. and fine fraction $<60 \%$ would be expected [32].

Table 2

Substrate properties

\begin{tabular}{|c|c|c|}
\hline Parameter & Value & Measuring method \\
\hline Bulk density, loose fill $\left[\mathrm{kg} / \mathrm{m}^{3}\right]$ & 342 & DIN EN ISO 17828 [33] \\
\hline Bulk density in reactor, average $\left[\mathrm{kg} / \mathrm{m}^{3}\right]$ & 496 & $\begin{array}{l}\text { DIN EN ISO } 17828 \text { [33] with } 60 \mathrm{~kg} \\
\text { layered compression }\end{array}$ \\
\hline Compression capability [\%] & 145 & - \\
\hline Moisture $W[\%]$ & 44 to 48 & DIN EN ISO 18134-1 [34] \\
\hline $\mathrm{C}: \mathrm{N}$ ratio & $25: 1$ & DIN EN ISO 16948 [35] \\
\hline Calorific value $c_{m}[\mathrm{MJ} / \mathrm{kg}$ d.m.] & 8.3 & DIN EN ISO 18125 [36] \\
\hline Particle size $[\mathrm{mm}]$ & $60 \%$ is $<3.15$ & DIN EN ISO 17827-1 [37] \\
\hline Organic matter content $O D M[\%$ d.m.] & 40.6 & DIN EN ISO 18122 [38] \\
\hline Analyse of chemical elements [\%] & $\begin{array}{c}\text { Carbon } 26.2 \\
\text { Sulphur } 0.2 \\
\text { Nitrogen } 0.95 \\
\text { Hydrogen } 3.03\end{array}$ & DIN EN ISO 16948 [35] \\
\hline
\end{tabular}


a)

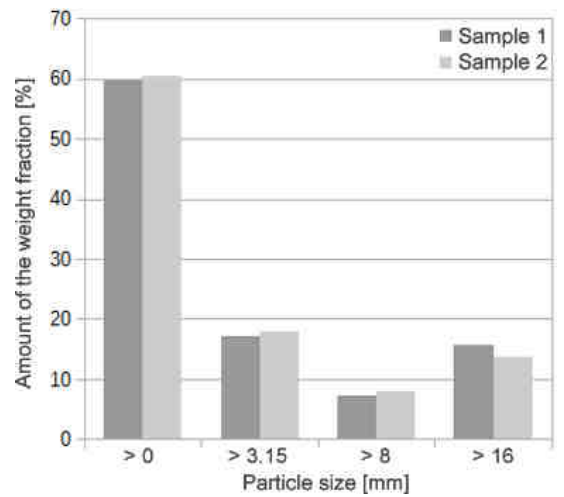

b)

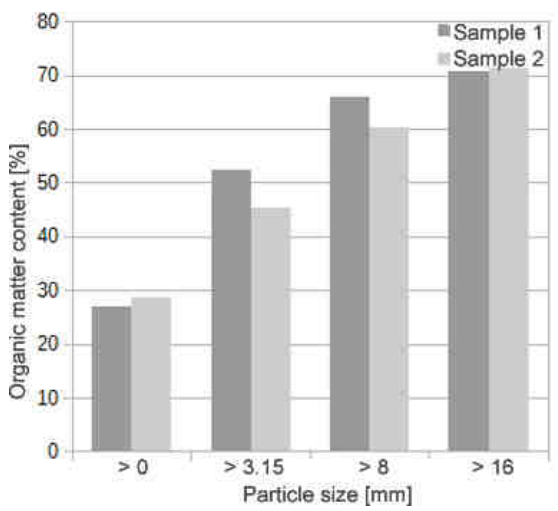

Fig. 4. a) Particle size distribution, b) organic matter of different particle sizes

Table 3 shows the properties of output material (compost after four month) in relation to its location in the reactor. The degradation degree $(\eta)$ decreases and the calorific value $\left(c_{m}\right)$ increases with larger distance to the reactor border $(s)$. This confirms that the biomass degraded significantly more in the areas supplied with oxygen due to aeration through the reactor border surface. The anaerobic core area remains less degraded conserves its heating potential nearly complete. As anaerobic degradation of lignin-cellulose biomass is least efficient and produces 6 times less heat [31]. Since aeration is related to the surface boundary, an increase in the diameter of cylindrical compost reactors would enlarge the anaerobic, low-degraded core zone and would not increase the heating power of the entire system.

Compost properties of reactor $4 \mathrm{~A}$ and $4 \mathrm{~B}$

\begin{tabular}{|c|c|c|c|c|c|}
\hline Area & $\boldsymbol{W}[\boldsymbol{\%}]$ & $\boldsymbol{O D M}[\boldsymbol{\%} \mathbf{d . m}]$. & $\boldsymbol{\eta}[\boldsymbol{\%}]$ & $\boldsymbol{c}_{\boldsymbol{m}}$ [MJ/kg d.m.] & C:N-Ratio [-] \\
\hline I. Border area & 42.0 & 25.8 & 49 & 5.5 & $21: 1$ \\
\hline II. Transmission area & 48.2 & 30.3 & 36 & 6.3 & $24: 1$ \\
\hline III. Core area & 45.8 & 35.7 & 22 & 8.8 & $36: 1$ \\
\hline
\end{tabular}

\section{Temperature development}

\section{Temperature range level depending on reactor size}

Boxplots of the core temperature sensor data after almost four month trial time are shown in Figure 5. Reactors with size category 1 drop more clearly in temperature range level over time than bigger reactors. This can be explained by the higher $A: V$ ratio and relatively higher heat loss through the surface boundary. In the trial time displayed, the reactors without heat extraction $(2 \mathrm{~A}, 2 \mathrm{C}, 3 \mathrm{~B})$ show a significantly higher temperature range level (median 55-60 ${ }^{\circ} \mathrm{C}$ ) than reactors with heat extraction $(2 \mathrm{~B}, 2 \mathrm{D}, 3 \mathrm{~A}, 4 \mathrm{~A}, 4 \mathrm{~B}-$ median $45-49{ }^{\circ} \mathrm{C}$ ) regardless of their size. This proves that with this internal heat exchangers, the reactor temperature can be controlled and heat can be removed. 


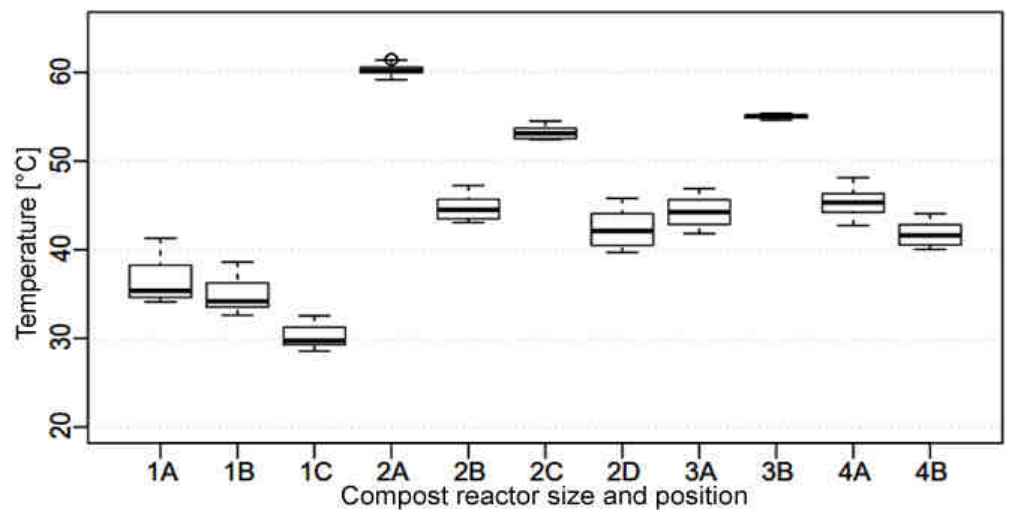

Fig. 5. Temperature of core temperature sensors, during trial time 112-127 days

\section{Temperature development depending on heat exchanger operation}

The temperature development of the reactors size category 2 are shown in Figure 7. The steady rise and fall of temperatures with the interval switching of the heat exchanger pumps (Fig. 6) is obvious. The longer heat exchanger pumps are not working, the higher temperature is rising. For Layer $1\left(h_{1}\right)$ and reactor $2 \mathrm{~A}$ and $2 \mathrm{C}$, a maximum temperature of $67{ }^{\circ} \mathrm{C}$ was reached. No data was obtained during rinse mode of heat exchanger, which was probably significantly lowering temperature in thermophilic phase.

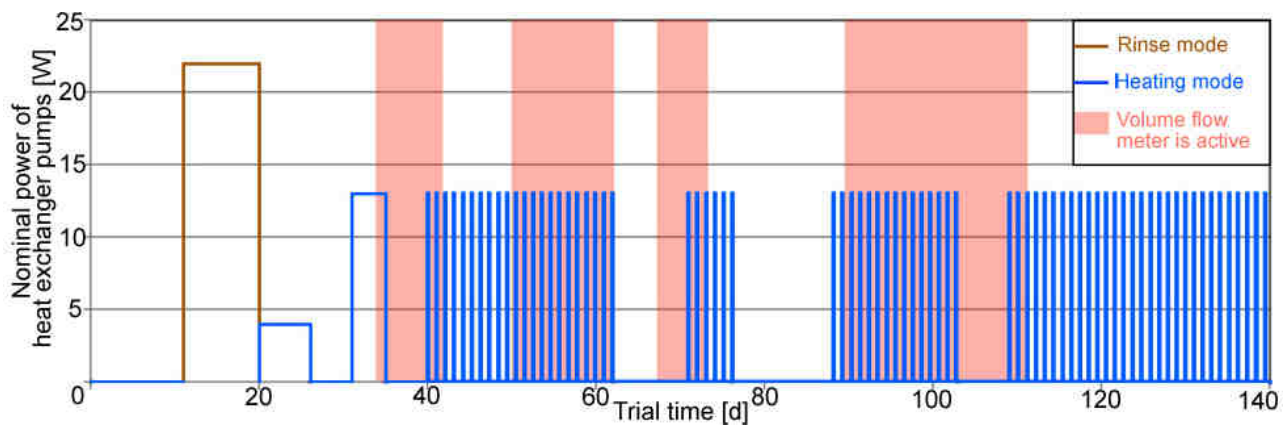

Fig. 6. Interval switching of the heat exchanger pumps, control system via nominal power setting

The temperature development of the reference reactor without heat extraction $(2 \mathrm{C}, 2 \mathrm{~A}$ after day 52) shows the expected behaviour of a conventional compost pile: A maximum, layer-dependent temperature was reached $\left(h_{1}: 67{ }^{\circ} \mathrm{C}, h_{2}: 53{ }^{\circ} \mathrm{C}, h_{3}: 54{ }^{\circ} \mathrm{C}\right)$ followed by a steady fall because of heat loss through surface area and convection as well as reduced microbial activity.

In reactors with heat extraction, the temperature response to heat exchanger pump switch off behaves like a heat storage: Charging of a capacitance. So the whole compost reactor - especially with a high water content - is used as self-loading buffer storage for heating purpose. It can be assumed that the gradient of temperature increase corresponds to the local heat production and depends on temperature range level, layer-specific maximum 
temperature and maximum local capacity charge. This behaviour is time-invariant and occurs even after 140 days of experiment (see reactor $2 \mathrm{~B}$ ). This supports the assumption that microorganism stay active at temperatures $<65^{\circ} \mathrm{C}$.

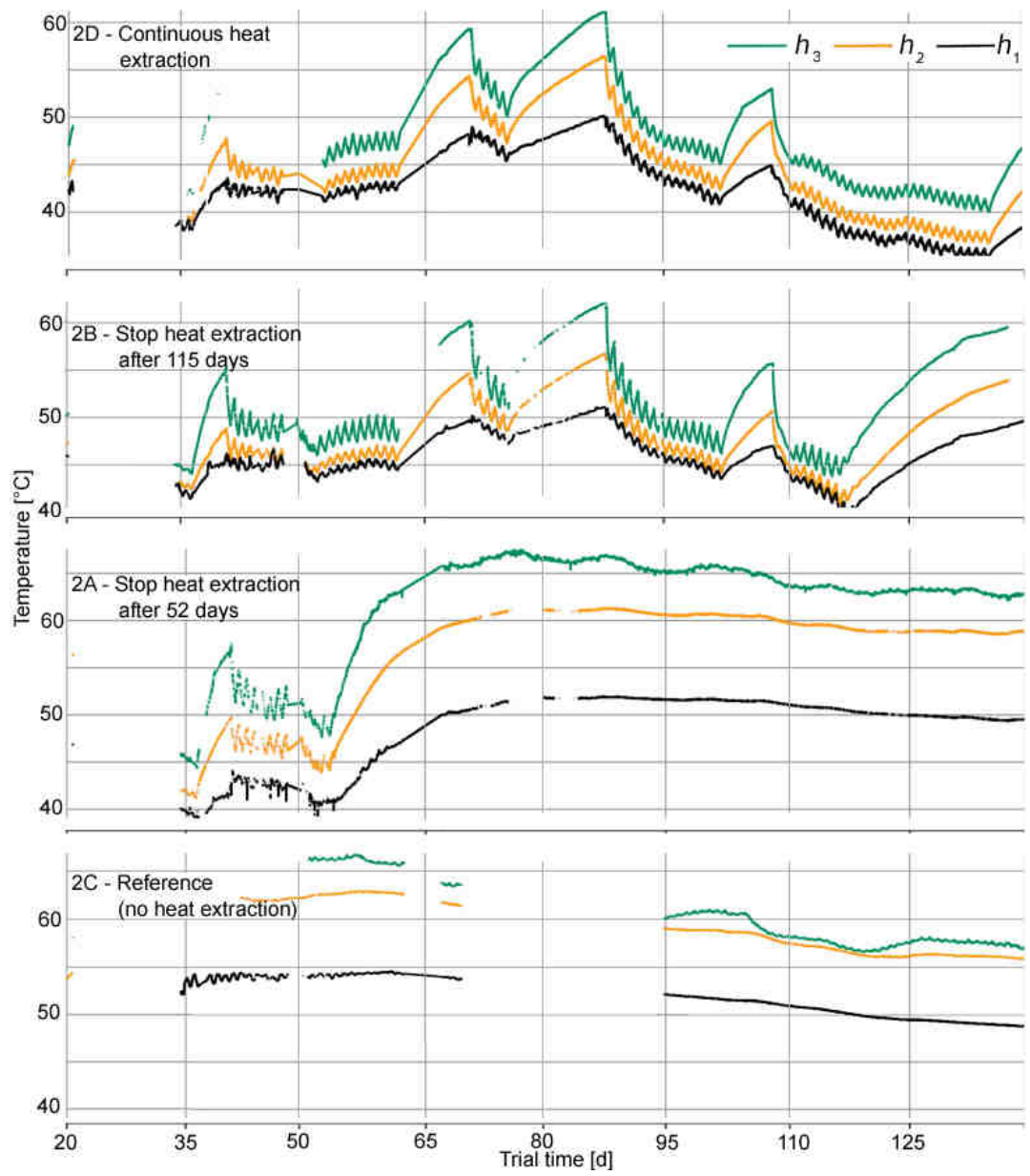

Fig. 7. Temperature development in reactors size category 2 depending on operational behaviour

\section{Vertical reactor profile of gas concentration and temperature}

Figure 8 shows reactors vertical gas concentration and temperature profiles of different times. $2 \mathrm{~B}$ is an example for a reactor with heat extraction, since only minimal differences are visible between reactor $2 \mathrm{~A}, 2 \mathrm{D}, 2 \mathrm{~B}$. Reactor $2 \mathrm{C}$ (reference reactor) is shown in Figure 9. In all reactors $\mathrm{O}_{2}$ is detectable only in the border area as no aeration units were installed. Gas concentration of $\mathrm{CO}_{2}$ is up to $40 \%$ and $\mathrm{CH}_{4}$ is up to $30 \%$ indicating an anaerobic fermentation process in the core area. For aerobic process the sum of gas concentrations of $\mathrm{O}_{2}$ and $\mathrm{CO}_{2}$ would be $21 \%$ [39]. The profile confirms that these static pile reactors are aerated only via the surface area despite installations (sensors, silo mesh, heat exchangers). 

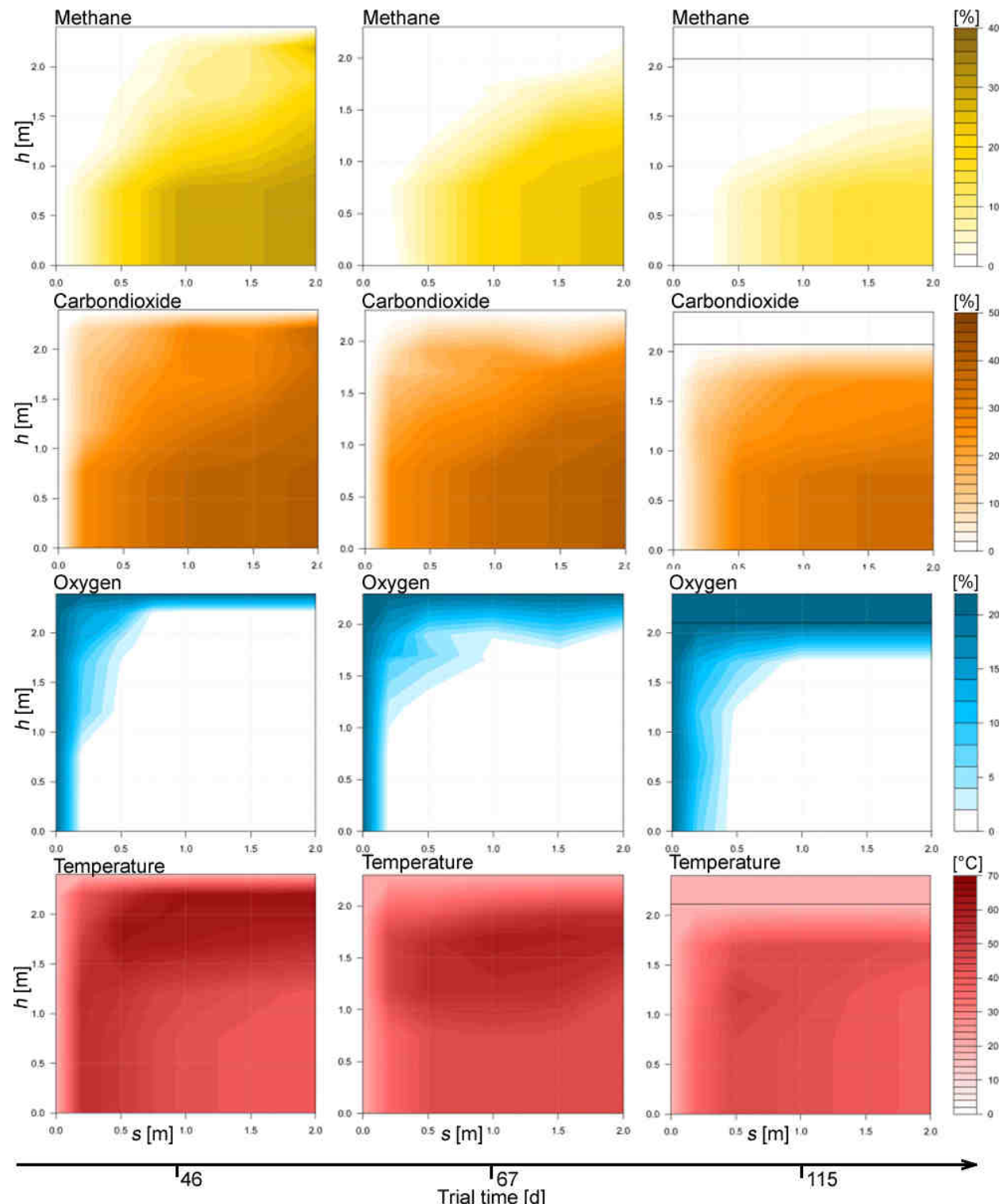

Fig. 8. Vertical profile of gas concentration and temperature, reactor with heat extraction (2B)

The pronounced bell shape of $\mathrm{CO}_{2}$ and $\mathrm{CH}_{4}$ up to day 64 illustrates the chimney effect, which carries air from anaerobic core area into the centre of the upper border area. This suggests emissions of greenhouse gases to the environment. The release of $\mathrm{CH}_{4}$ and $\mathrm{CO}_{2}$ decreases over time due to the progressive composting process, as less nutrients are available for biochemical conversion. This behaviour is also observed in not sufficient 
operated industrial composting. The total amount of released greenhouse gases can not be estimated from this study and should be investigated in future studies.
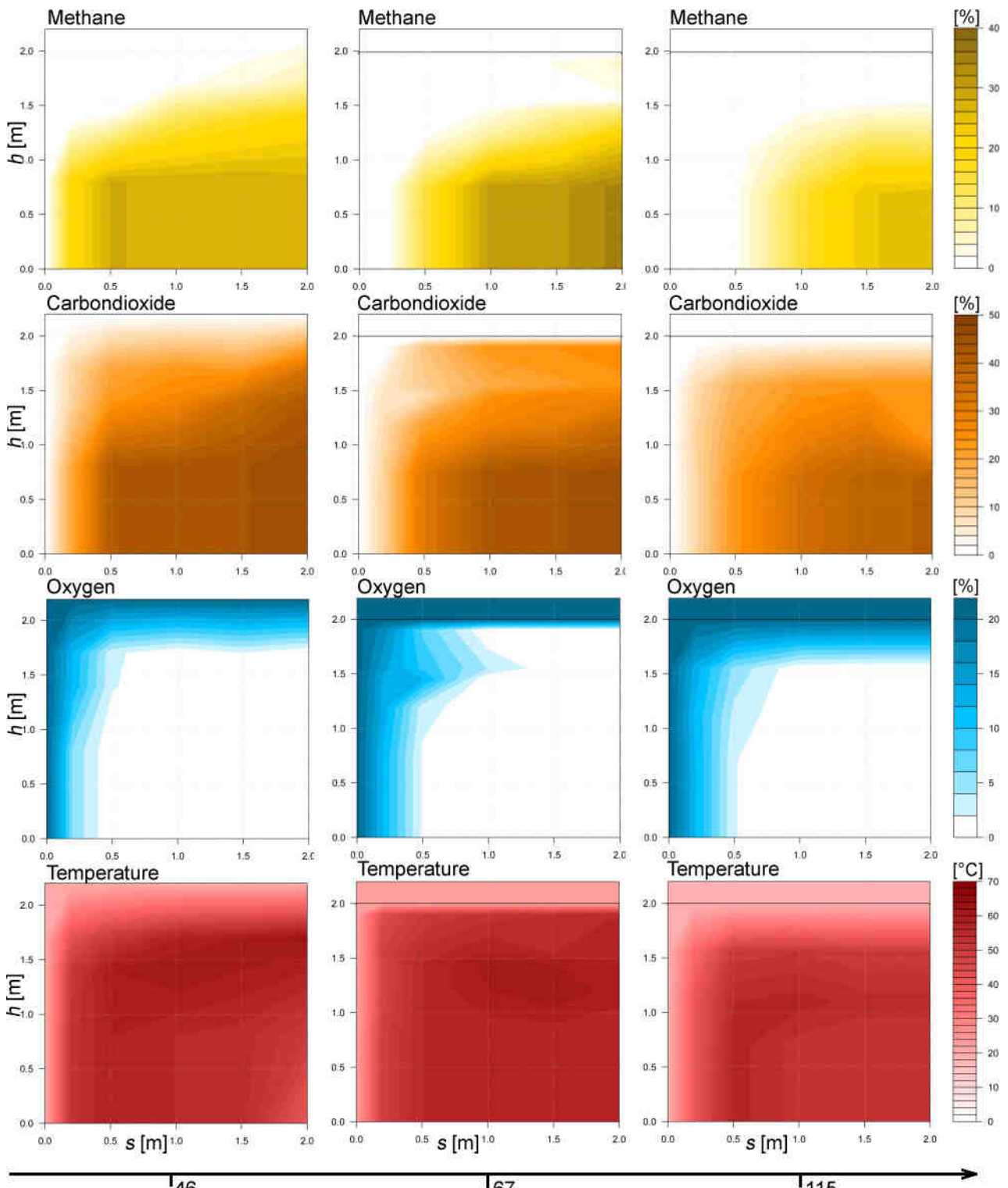

$T_{46}$

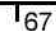

Trial time [d]

Fig. 9. Vertical profile of gas concentration and temperature, reactor without heat extraction (2C)

Because of the compaction effect the bulk density decreases with increasing height of the reactor. This may leads to differences in the vertical and horizontal development of the 
border area (aeration via surface), because regions of lower bulk density have more pore volume for convective gas exchange. Convective gas exchange also carries out moisture from the composting process. So the border area is drying out over time. Thus, it acts as an insulation layer and - in case of rain events - as a buffer area.

To determine the influence of heat extraction on the composting process, all reactors of size category 2 (including gas concentration and temperature profiles of 2A, 2D that are not shown here) were compared. It was noticed that there are no differences (apart from the expected measurement failure range) in the maximum gas concentration of $\mathrm{O}_{2}, \mathrm{CO}_{2}$ and $\mathrm{CH}_{4}$ throughout the whole experimental period. Therefore, the difference in temperature range levels (Fig. 5) and heat extraction (Table A.4) are assumed to have no influence on the biochemical decomposition processes of the reactors.

\section{Recovered heating power and influence factors}

For the evaluation of recovered heating power and its influence factors, about $25 \%$ of the trial time can be included, in which both the pumps and the volumetric flow sensors were active (Fig. 6). Therefore, four different time periods were defined (34-43 d, 53-62 d, 96-105 d, 109-112 d) and the recovered heating power of reactors were calculated (eq. (2)) within these time periods (Table A.4).

Evaluation of this data shows that the heat exchanger volume flows $(\dot{V})$ varied between 3.5-10 L/min, depending on reactor size and trial time period. Cases where $\dot{V}$ was $<2 \mathrm{~L} / \mathrm{min}$ were caused by poor maintenance and poor set-up quality of the heating circuit, e.g. when air accumulated in pipe loop heat exchangers. Return flow temperatures $\left(\vartheta_{r}\right)$ were $30-45^{\circ} \mathrm{C}$ and depend on size of consumers which was different for each reactor. Therefore, it can be assumed that the reactors in this experiment are not operated optimally for recovering heating power, since $\dot{V}$ and $\vartheta_{r}$ were not fully controlled. Recovered heating power $\dot{Q}>2 \mathrm{~kW}$ were achieved by reactors $2 \mathrm{D}(2.3 \mathrm{~kW}, t>96 \mathrm{~d}), 4 \mathrm{~A}(5.2 \mathrm{~kW}, t>96 \mathrm{~d})$ and $4 \mathrm{~B}(3.6 \mathrm{~kW}, t>109 \mathrm{~d})$ with a maximum of $5.2 \mathrm{~kW}(4 \mathrm{~A}) .5 .2 \mathrm{~kW}$ are about $10 \%$ less recovered heating power as expected for a $70 \mathrm{~m}^{3}$ size reactor from the commercial builder. They claim a time-independent recoverable heating power of $1 \mathrm{~kW}$ per $10 \mathrm{~m}^{3}$ substrate used which would be equivalent to $6 \mathrm{~kW}$ for $60 \mathrm{~m}^{3}$ (4A). The heating power of reactors size 1 show a tendency to decrease over time and the heating power of reactors size 2-4 show a tendency to increase over time, provided that the process conditions are comparable. Based on these findings and the findings of the gas concentration and temperature range level analyses (Fig. 5) we propose: The recoverable heating power doesn't increase linearly with reactor size, but reactors with higher volume can maintain the heating power over a longer period of time.

To estimate the overall energy efficiency of the studied system, the maximum recovered heating power observed in this study $(5.2 \mathrm{~kW}, 4 \mathrm{~A})$ was taken and assumed as heating power for continuous 3 months of optimal operation. This is equivalent to the actual operation time of reactors $4 \mathrm{~A} \& 4 \mathrm{~B}$ due to starting delay. The substrate-specific amount of thermal energy extracted for this scenario was calculated to be $2.4 \mathrm{MJ} / \mathrm{kg}$ d.m., which corresponds to the decrease of calorific value of the substrate material of transmission area (Table 3). Compared with internal heat exchangers in literature, a recovered heating power for a 6 month period of $4.8 \mathrm{MJ} / \mathrm{kg} \mathrm{d}$.m. (approximately $50 \%$ of calorific value) concurs with values found by Schuchardt [18]. There are hardly any systematic studies on maximum recoverable heat amounts of composting processes [40]. Other authors confirmed 
by their experiments recovered heat amounts of 30-50\% of calorific value [32, 41]. Lower heat amounts from literature of $5-30 \%[21,41]$ were attributed to inefficient operating modes.

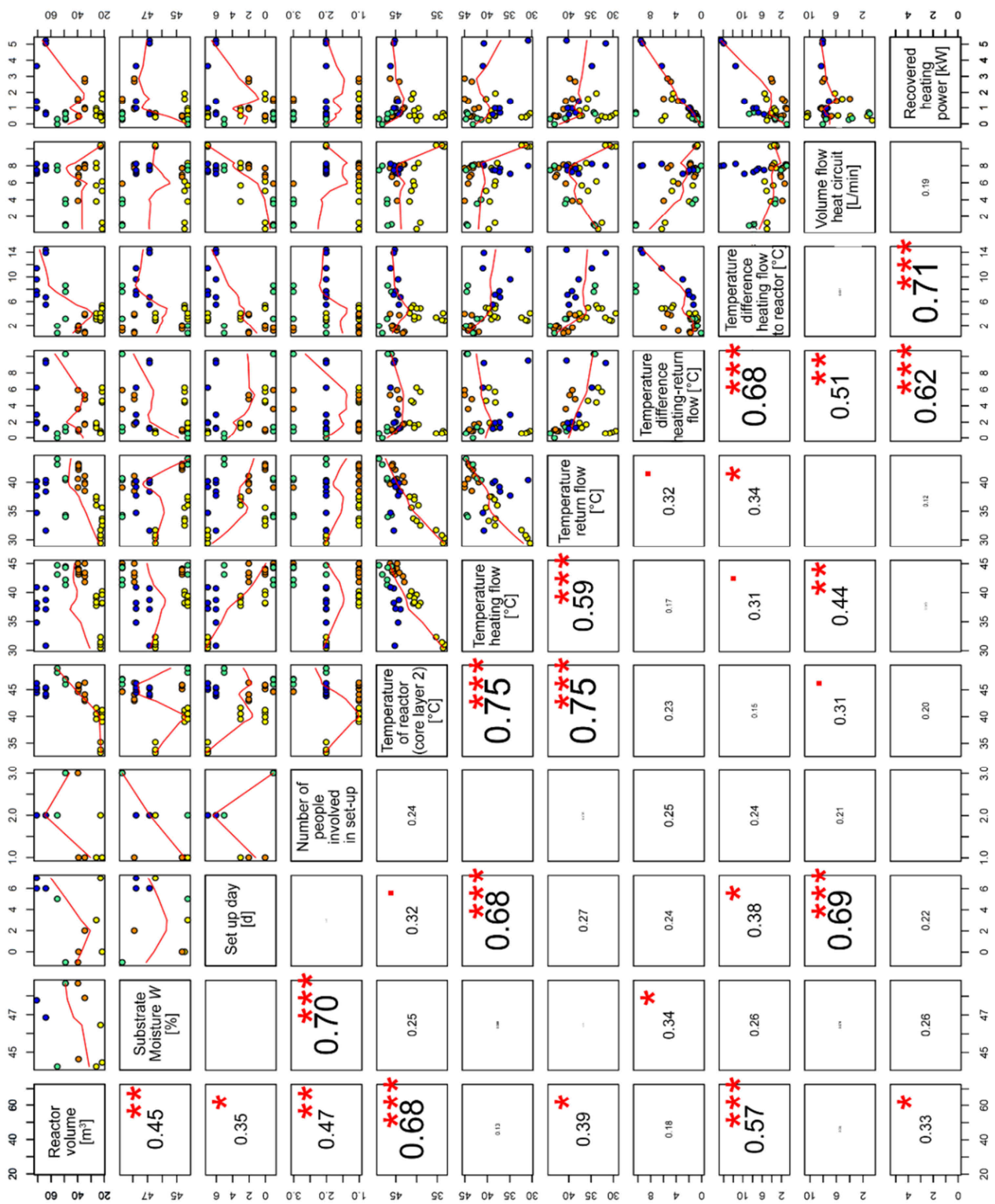

Fig. 10. Correlation-matrix for detected influence factors on recovered heating power 
A statistical correlation of all factors was performed with the statistic program $\mathrm{R}$ to find influence factors on maximum recovered heating power (Fig. 10). The correlation matrix shows diagrams and corresponding correlation values mirrored on the diagonal axis. Factors with high influence have a high $p$-value and red marks. As expected, the recovered heating power depends on $\dot{V}$ and $\left(\vartheta_{h}-\vartheta_{\mathrm{r}}\right)$ (eq. (2)). Additional dependencies are:

- non-linear increasing with volume flow, maximum at approx. 6-8 L/min

- direct linear increasing with temperature difference of return flow and reactor

- non-linear increasing with the temperature level in the reactor

- non-linear increasing with volume, since reactor size $2 \& 4$, especially with trial time

$>80$ days achieve higher performance than reactor size

Surprisingly, the quality of reactor set up and the experience of the builders (set-up day of reactor) had also an influence on the possible extraction of heat. This was because of the complex process preparation for which the experience was necessary for watering, substrate quality, use and reliability of the technical supply. Additionally, a direct dependency of the reactor temperature and the temperature of heating flow (outcoming) was found, since the heat exchanger is suitable for removing heat energy from the compost reactor.

\section{Conclusion and outlook}

Substrate investigations showed optimal conditions for the composting process in terms of $\mathrm{C}: \mathrm{N}$ ratio and water content but suboptimal conditions in terms of calorific value and high fine fraction. The compost reactors with a diameter of 4-5 $\mathrm{m}$ were investigated in more detail regarding their gas development. It was found that there is a high production of methane (up to $30 \%$ ) and carbon dioxide (up to $40 \%$ ) in the core area of the reactors. Due to the occurrence of the chimney effect, a leakage of emissions is very likely in the trial period of up to 60 days. This suggests that there was an anaerobic fermentation process in the core area with only little heat generation due to lack of oxygen supply. The air supply took place exclusively via the reactor surface area and heat production was taking place in the aerated areas. This is confirmed by the substrate investigations of the composted material from the core area. Here, hardly any decomposition of organic matter was achieved and the calorific value remained almost unchanged. In the future, it would be necessary to install components to ensure an air supply. One suggestion would be the use of the dome aeration for flexible oxygen supply to avoid emissions and increase the recoverable heating power (without additional energy usage) [32, 39]. Furthermore, the high content of fine fraction in the substrate contributes to a reduced aeration, as the pore volume is smaller. In the future, the choice of a higher particle size or less fine fraction can have a positive influence in terms of aeration but may not in degradation rate. Also, internal installations such as the silo mesh can lead to a reduced air supply and the influence of these internal installations should be critically reviewed.

As expected, the size of the reactors plays a role in heat released. Small reactors tend to have a higher heat loss due to a less favourable $A: V$ ratio and can maintain temperature level and heating power for a shorter period of time $(<90 \mathrm{~d})$. The heat exchangers are suitable for heat extraction and temperature control in the reactor (aeration independent), as they significantly reduce the temperature level. The temperature curve suggests that compost material functions as a buffer storage. A maximum recovered heating power of $5.2 \mathrm{~kW}$ was detected. Influence factor analyses show shortcomings in set-up quality and operational behaviour, as this technology has only been used in the semi-professional sector 
so far. In future for optimal heating power, the volume flow $(2-8 \mathrm{~L} / \mathrm{min})$ and the return temperature $\left(30-45^{\circ} \mathrm{C}\right)$ would have to be systematically varied in order to investigate an optimal operating mode and heating integration (consumer, storage) to estimate realistically the potential of this technology and its role in the energy system transformation.

\section{Acknowledgements}

The project underlying this report was funded by the German Federal Ministry of Education and Research (BMBF) under grant number 031B0244. The responsibility for the content of this publication lies with the authors. This research would not have been possible without the expert advice of Dr. Joachim Brummack from TU Dresden and the committed work of Heiner Cuhls of Native Power e.V., Max Koch from Green Energy Monitoring and Hannes Jaschke.

\section{Abbreviations and symbols}

\begin{tabular}{|c|c|c|}
\hline Abbreviations & Description & Units \\
\hline$A: V$ ratio & Surface area to volume ratio & - \\
\hline C:N ratio & Carbon to nitrogen ratio & - \\
\hline d.m. & Dry matter & - \\
\hline MP & Manual measurement points & - \\
\hline$O D M$ & Organic dry matter & {$[\%$ d.m.] } \\
\hline$\varnothing$ & Mean & - \\
\hline$h_{1 . .3}$ & Reactor height of level 1 to 3 & {$[\mathrm{m}]$} \\
\hline$\vartheta_{1 . .3}$ & $\begin{array}{c}\text { Temperature of height level } \\
1 \text { to } 3\end{array}$ & {$\left[{ }^{\circ} \mathrm{C}\right]$} \\
\hline$\vartheta_{h}, \vartheta_{r}$ & $\begin{array}{c}\text { Temperature of heating } \\
\text { and return flow }\end{array}$ & {$\left[{ }^{\circ} \mathrm{C}\right]$} \\
\hline$c_{w}$ & Heat capacity of water & {$[\mathrm{J} / \mathrm{kg}]$} \\
\hline$\rho_{W}$ & Density of water & {$\left[\mathrm{kg} / \mathrm{m}^{3}\right]$} \\
\hline
\end{tabular}

\begin{tabular}{|c|c|c|}
\hline Symbols & Description & Units \\
\hline$c_{m}$ & Calorific value of material & {$[\mathrm{J} / \mathrm{kg}]$} \\
\hline$h$ & Height of reactor & {$[\mathrm{m}]$} \\
\hline$r$ & Radius & {$[\mathrm{m}]$} \\
\hline$s$ & $\begin{array}{c}\text { Distance from reactor } \\
\text { border }\end{array}$ & {$[\mathrm{m}]$} \\
\hline$t$ & Trial time & {$[\mathrm{s}]$} \\
\hline$W$ & Water content & {$[\%]$} \\
\hline$V$ & Volume of reactor & {$\left[\mathrm{m}^{3}\right]$} \\
\hline$\dot{V}$ & $\begin{array}{c}\text { Volume flow heat } \\
\text { exchanger circuit }\end{array}$ & {$\left[\mathrm{m}^{3} / \mathrm{s}\right]$} \\
\hline$\dot{Q}$ & Heating power & {$[\mathrm{W}]$} \\
\hline$\vartheta$ & Temperature & {$\left[{ }^{\circ} \mathrm{C}\right]$} \\
\hline$\eta$ & Degradation degree & {$[\%]$} \\
\hline
\end{tabular}

\section{References}

[1] 52016DC0051:2016-02. EU Strategy on Heating and Cooling. European Commission. Communication from the Commission to the European Parliament, the Council, the European economic and social committee and the Committee of the Regions. Available from: https://eur-lex.europa.eu/legalcontent/en/TXT/?uri=CELEX:52016DC0051.

[2] Federal Ministry of Economic Affairs and Energy. Time series for the development of renewable energy sources in Germany 1990-2021. Berlin: 2021. Available from: https://www.erneuerbareenergien.de/EE/Navigation/DE/Service/Erneuerbare_Energien_in_Zahlen/Zeitreihen/zeitreihen.html en.pdf;jsessionid=7E3EC118E76717EF6EC854AEEC411E27?_blob=publicationFile\&v=13.

[3] 32018L2001:2018-12. The promotion of the use of energy from renewable sources. European Parliament and of the Council. Available from: https://eur-lex.europa.eu/legalcontent/EN/TXT/?uri=CELEX:32018L2001.

[4] Federal Ministry of Science and Education. Bioökonomie in Deutschland (Bioeconomy in Germany). Bonn, Berlin: 2014. Available from: https://www.bmbf.de/upload_filestore/pub/Biooekonomie_in_ Deutschland.pdf.

[5] Brosowski A, Brosowski A, Thrän D, Mantau U, Mahro B, Erdmann G, et al. A review of biomass potential and current utilisation; Status quo for 93 biogenic wastes and residues in Germany. Biomass Bioenergy. 2016;95:257-72. DOI: 10.1016/j.biombioe.2016.10.017.

[6] Osterburg B, Schüler M, Klages S. Auswirkungen der Novelle der Düngeverordnung auf die Kompostanwendung in der Landwirtschaft (Effects of the Fertilizer Directive Novel on the Application of Compost in Agriculture). Braunschweig: Thünen-Institut; 2016. Available from: 
https://www.kompost.de/fileadmin/user_upload/Dateien/HUK-Dateien/1_2_2016/Kompost_und_DueV-

Novelle_Zwischenbericht_1_2016_v6.pdf.

[7] 31991L0676:1991-12/2008. Protection of waters against pollution caused by nitrates from agricultural sources. European Council Directive. Available from: https://eur-lex.europa.eu/legalcontent/EN/TXT/?uri=celex\%3A31991L0676.

[8] Richter F, Kern M, Raussen T, Wagner J. Optimierung der Erfassung, Aufbereitung und stofflich-energetischen Verwertung von Grüngut in Deutschland (Optimization of the collection, processing and material and energy recovery of green waste in Germany). Witzenhausen: Witzenhausen-Institut; 2019. Available from: https://www.energetische-biomassenutzung.de/fileadmin/Steckbriefe/dokumente/ 03KB107_Gr\%C3\%BCn-OPTI_Schlussbericht.pdf.

[9] Hoffman H, Kern M. Weiterentwicklung der stofflichen und energetischen Verwertung von Biomasse beim Zweckverband regionale Abfallwirtschaft (Further development of the material and energetic utilization of biomass at the association of regional waste management). Witzenhausen: Witzenhausen-Institut; 2011. Available from: http://regent.art-trier.de/upload/dokumente/10372.pdf.

[10] Smith MM, Aber JD, Rynk R. Heat recovery from composting: A comprehensive review of system design, recovery rate, and utilization. Compost Sci Utilization. 2016;0:1-12. DOI: 10.1080/1065657X.2016.1233082.

[11] Müller N. Untersuchung zum Betriebsverhalten von Biomeilern (Operational Behaviour of Compost Reactors with Heat Recovery). Dresden: Technical Universiät Dresden; 2017. Available from: https://nbn-resolving.de/urn:nbn:de:bsz:14-qucosa2-709495.

[12] Zhao R, Guo H, Gao W, Tong G. Literature Review on Composting Heat Recovery. CSBE/SCGAB 2015 Annual Conf. Edmonton, Alberta: The Canadian Society for Bioengineering; 2015. Available from: https://library.csbe-scgab.ca/docs/meetings/2015/CSBE15136.pdf.

[13] Petiot C, De Guardia A. Composting in a laboratory reactor: A review. Compost Sci Utilization. 2004;12:69-79. DOI: 10.1080/1065657X.2004.10702160.

[14] Wang Y, Pang L, Liu X, Wang Y, Zhou K, Luo F. Using thermal balance model to determine optimal reactor volume and insulation material needed in a laboratory-scale composting reactor. Bioresour Technol. 2016;206:164-72. DOI: 10.1016/j.biortech.2016.01.097.

[15] Lashermes G, Barriuso E, Le Villio-Poitrenaud M, Houot S. Composting in small laboratory pilots; Performance and reproducibility. Waste Manage. 2012;32:271-7. DOI: 10.1016/j.wasman.2011.09.011.

[16] Fulford B. The Composting Greenhouse at New Alchemy Institute: A Report on Two Years of Operation and Monitoring March 1984-January 1986. Hatchville: New Alchemy Institute; 1986. ISBN: 093382209X.

[17] DE3932765A1:1991-09. Bio:heat incubator; Heats greenhouse using hot air from rotting compost. Patent. Available from: https://depatisnet.dpma.de/DepatisNet/depatisnet?action=bibdat\&docid= DE000003932765A1.

[18] Schuchardt F. Wärmeentzug bei der Kompostierung von Schnittholz (Heat extraction during composting of greencut wood). Landbauforschung Völkenrode. 1984;34:189-95. Available from: https://literatur.thuenen.de/digbib_extern/dk016224.pdf.

[19] Schuchardt F. Versuche zum Wärmeentzug aus Festmist. Landbauforschung Völken-Rode. 1983;33:169-78. Available from: https://literatur.thuenen.de/digbib_extern/dk001577.pdf.

[20] Vemmelund N, Berthelsen L. A note on heat recovery from mechanically aerated farm-yard manure. Agricultural Wastes. 1979;1:157-60. Available from: https://www.sciencedirect.com/journal/agriculturalwastes/vol/1/issue/2.

[21] Viel M, Sayag D, Peyre A, André L. Optimization of in-vessel co-composting through heat recovery. Biological Wastes. 1987;20:167-85. DOI: 10.1016/0269-7483(87)90152-2.

[22] Winship EAN, Holmes D, Notion D. Combined heat and composting; In moving organic waste recycling toward resource management and biobased economy. Orbit 6th International Conference - Moving Organic Waste Recycling towards Resource Management and for Biobased Economy, 2008;1451-1463. Wageningen, Netherlands. Available from: https://www.researchgate.net/profile/Marina-RodriguezDiaz/publication/266509055_effect_of_urban_sewage_sludge_compost_on_bacterial_biodiversity_and_soil _enzymatic_activities/links/5433c4620cf2dc341dada0b3/effect-of-urban-sewage-sludge-compost-onbacterial-biodiversity-and-soil-enzymatic-activities.pdf.

[23] Smith M, Aber J. Heat Recovery from Compost; Guide to Building an Aerated Static Pile Heat Recovery Composting Facility. New Hampshire: University of New Hampshire; 2017. DOI: 10.13140/RG.2.2.22893.23520.

[24] Di Maria F, Postrioti L, Micale C, Sordi A, Marconi M. Energy recovery from low temperature heat produced during aerobic biological treatment. Energy Procedia. 2014;45:81-90. DOI: 10.1016/j.egypro.2014.01.010. 
[25] Irvine G, Lamont ER, Antizar-Ladislao B. Energy from waste; Reuse of compost heat as a source of renewable energy. Int J Chem Eng. 2010;ID627930. DOI: 10.1155/2010/627930.

[26] Di Maria F, Benavoli M, Zappitelli M. Thermodynamic analysis of the energy recovery from the aerobic bioconversion of solid urban waste organic fraction. Waste Manage. 2008;28:805-12. DOI: 10.1016/j.wasman.2007.03.021.

[27] Soyez K, Koller M. Verfahrensentwicklung zur Kopplung von Kompostierung und Gewächshausproduktion - BMBF-Verbundvorhaben „Neue Techniken zur Kompostierung“ Teilvorhaben TV3/1-3 (Process development for the integration of composting and greenhouse production - BMBF joint "New techniques for composting" TV3/1-3). Potsdam: German Environmental Agency; 1996. Available from: http://worldcat.org/identities/viaf-148589293.

[28] Jaccard L, Lehmann P, Civilini M, Bertoldi M de. Yard waste composting with heat recovery. Compost Sci Utilization. 1993;1:10-4. DOI: 10.1080/1065657X.1993.10757882.

[29] Seki H, Komori T. Packed-column-type heating tower for recovery of heat generated in compost. J Agricult Meteorology. 1992;48:237-46. DOI: 10.2480/agrmet.48.237.

[30] Konrad K. Einfache und verlässliche Berechnung des oTS-Abbaugrades in Biogasanlagen (Simple and reliable calculation of the oTS degradation level in biogas plants). Biogas Forum Bayern III -16/2015, Hrsg. ALBBayern e.V. Available from: http://www.biogas-forum-bayern.de/media/files/0001/Einfache-undverlassliche-Berechnung-des-oTS-Abbaugrades-in-Biogasanlagen.pdf.

[31] Epstein E. Industrial Composting; Environmental Engineering and Facilities Management. Boca Raton: CRC Press Inc; 2011. ISBN: 9781439845318.

[32] Schmidt-Baum T, Jaschke N. Mehrkammer-Biomeiler. Neue Möglichkeiten zur Schließung regionaler Energie- und Stoffkreisläufe durch flammenlose energetische Nutzung von Reststoffen (Multi-chamber compost reactor; New possibilities for closing regional energy and material cycles through flameless energetic use of residual materials). Rostocker Bioenergieforum. 2020:329-39. Rostock: Nelles M; 2020. Available from: https://bioenergieforum.auf.uni-rostock.de/files/Tagungsband.pdf.

[33] DIN EN ISO 17828:2016-05. Solid biofuels - Determination of bulk density. Available from: https://www.beuth.de/de/norm/din-en-15103/124227785.

[34] DIN EN ISO 18134-1:2015-12. Solid biofuels - Determination of moisture content - Oven dry method - Part 1: Total moisture - Reference method. Available from: https://www.beuth.de/de/norm/din-en-iso-18134$1 / 232359808$.

[35] DIN EN ISO 16948:2015-09. Solid biofuels - Determination of total content of carbon, hydrogen and nitrogen. Available from: https://www.beuth.de/de/norm/din-en-iso-16948/222780653.

[36] DIN EN ISO 18125:2017-08. Solid biofuels - Determination of calorific value. Available from: https://www.beuth.de/de/norm/din-en-iso-18125/266725966.

[37] DIN EN ISO 17827-1:2016-10. Solid biofuels - Determination of particle size distribution for uncompressed fuels - Part 1: Oscillating screen method using sieves with apertures of 3,15 mm and above. Available from: https://www.beuth.de/de/norm/din-en-iso-17827-1/242406902.

[38] DIN EN ISO 18122:2016-03. Solid biofuels - Determination of ash content. Available from: https://www.beuth.de/de/norm/din-en-iso-18122/233573333.

[39] Brummack J. Das Dombelüftungsverfahren; Ein vielseitig einsetzbares Belüftungsverfahren für offene Rottemieten auch nach 2005 (The dome aeration process; A versatile aeration process for outdoor rotting windrows even after year 2005). Abfallforschungstage 2004. Karlsruhe: Wasteconsult; 2004. Available from: http://www.wasteconsult.net/files/downloads/2004-E18_Brummack\%20Dombelueftung1.pdf.

[40] Nwanze K, Clark G. Optimizing heat extraction from compost. Compost Sci Utilization. 2015;27:1-10. DOI: 10.1080/1065657X.2019.1686443.

[41] Lekic S. Possibilities of Heat Recovery from Waste Composting Process. Cambridge: University of Cambridge, Centre for Sustainable Development; 2005. Available from: https://www-esdmphil.eng.cam.ac.uk/about-the-programme/dissertations/students/SnezanaLekic. 